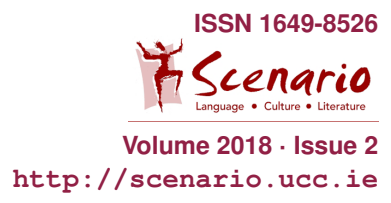

Short Presentation - 6th Scenario Forum Symposium

\title{
On the art of reflection in the arts!
}

\author{
Niklas Hald
}

I was invited to the symposium in order to hold the workshop $A$ crash course in $R P K$ (Reflections on Practical Knowledge). Since I work both as a lecturer and as an actor, and of one the key ingredients in RPK is reflecting on our personal experiences, I thought the best way of introducing my workshop, during the introductory Sunshine speeches, would be through telling a story about my life as an actor.

This story starts with myself as a young actor performing for small children. It all begins in an early November morning with chaotic weather, snowstorm and myself as the "lone hero" trying to solve everything that comes in my way, being late and constantly exposed to new problems. After running around like a mad man on a problem-solving mission while building the set, I can finally open the doors and let the young audience in. However, a couple of minutes into the performance I hear a young girl say loudly: "When does the theatre begin?"

I've used this story in a lot of situations to explain some of the circumstances I can face as an actor in a small company on tour. To me it is a typical story, being both revealing and funny at the same time. In the beginning, I always told it as an example of how ungrateful an actors life can be. After a couple of years though, the story took another shape.

By then I had begun a course in what we, at the Stockholm University of the Arts, call Reflections on practical knowledge, and was busy writing an essay on acting. Among other things, I asked myself the question: How do I prepare before a performance? Then the old story came into my mind again, but from a new perspective. I realised I had done and achieved a lot of things that morning, technical, practical stuff, but I had not had the time to properly prepare as an actor about to play a part in front of an audience. From that perspective, the girls question: "When does the theatre begin?" might have been spoken because she had detected that something was missing. The true and communicative presence of an actor on stage.

Yet another couple of years later, a friend told me the story of when she took her grandchild to the theatre for the first time in the young girls life. They went to see Peter and the Wolf, and they both liked it very much. When the grandmother some weeks later asked the girls if she wanted to go to the theatre again, the girl immediately said "Yes!" This time it was another play, in another theatre and the young girls enthusiasm seemed to wane after only of couple of minutes in to the play. She sunk back into her grandmothers lap and whispered: "Where is the wolf?" 
For this girl, theatre meant that there would be an imaginary wolf involved! Once more, this brought new light on my first story. Having started as an anecdote about the "hard life" of a touring actor and the feeling of obscurity that sometimes accompanies, the story had already gained a new depth when I saw the connection to my own role in the whole. It had become a story of the fragile encounter with the audience and what a performance requires of me as an actor, each time. Now I added another dimension, one about what theatre represents for those in the audience. What is a theatre performance? What is theatre? When and where does it begin?

Reflection on practical knowledge is about discussing and examining the phenomenon of a tradition or a specific situation. One way of doing this is trying to answer the question: What are we doing when we are doing what we do? Next step can then be to reflect on: Why we are doing what we are doing. Being an actor performing for children in schools, I am automatically part of a pedagogical process. At the same time, not all of my colleagues would agree, and I also feel there is a gap between the theatre community and that of theatre pedagogues. That is why it is useful for me to take part in the Scenario Forum symposiums, even if I sometimes feel like the odd man out. In a context like this when we gather to talk about performativity as a tool for learning other things, language etc., being an actor can feel strange. To me performativity has always been connected with theatre and acting as a practise. My given role as an actor is to imagine, invent and perform different characters in front of other people. When I act on stage or teach my acting students more about acting, performativity is not just process on the way to something else, it is a goal in itself.

However, that statement challenges the idea of why I am performing. If I want my audience to experience something in their minds and bodies, I have to establish a contact. This contact takes place during the performance, since to perform is to communicate. Some actors have issues with acknowledging the connection between theatre and pedagogical work. But, when I am out in the schools, playing for children and young people, I use the play my colleagues and I have shown our audience, to discuss and reflect upon the topics that we find in it. The characters we have played becomes an alibi for the children in order to discuss matters that can be hard to talk about in a situation where personal issues and confessions can be hard to reveal in front of the other children. So, instead of asking: "How would you feel if your friend lied to you?" I can ask "How do you think Othello felt when he realized Jago had lied to him?" Here, the performance becomes a part of a pedagogical process that most of my acting colleagues can accept.

My workshop at the symposium took its starting point in the circular motion of my original story and all of its aspects. All participants wrote a short story based on a true experience in their own professional life. A story about a complicated or just complex event that for different reasons has stayed in their memories. Then they told and discussed these stories with the other participants, before writing again about what came up in the discussions and what they thought 
about it all now.

This way of using personal stories is sometimes questioned by the traditional research community. Oddly enough, it is also questioned by members of the artistic research field. There it is looked upon as too theoretical, and not artistic enough. However, telling stories is to me a highly performative way of communicating and a great way to understand others and myself. The circular motion of reflecting upon personal experiences and allowing other peoples thoughts into the process, to me has become a useful tool as an actor, researcher and teacher. It allows me to use philosophical, theoretical and pedagogical insights in my theatrical work as well as introducing my performative practice into my research and teaching. In my role as a teacher all these forms blend in to one. My struggle is to find the methods and schemes most useful in the situation I am in with my students. The overall goal is to be able not only to discuss the "what do I do?" and "how do I do it?" but also to constantly have us all remember, "why we do it".

One answer to the question "why?" is that to me, performing theatre, as all arts, means taking part in a conversation about what it means to be a human being. Another one is, because it useful and fascinating in so many ways regardless of context and level of professionalism. The initial question of "When does the theatre begin?" has many answers. The easiest might be "When we want it to!" 